\title{
THE NATURAL RADIONUCLIDES IN SOILS OF SUBOTICA (SERBIA): DISTRIBUTION AND CORRESPONDING GAMMA DOSE RATES
}

\author{
Lj. Janković Mandić ${ }^{*}$, R. Dragovićé ${ }^{2}$ S. Pisanjuk³, S. Dragović ${ }^{1}$ \\ ${ }^{1}$ University of Belgrade, Vinča Institute of Nuclear Sciences, Belgrade, Serbia \\ ${ }^{2}$ University of Niš, Faculty of Science and Mathematics, Niš, Serbia \\ 3University of Belgrade, Faculty of Physical Chemistry, Belgrade, Serbia
}

\begin{abstract}
The activity concentrations of ${ }^{40} \mathrm{~K},{ }^{226} \mathrm{Ra}$ and ${ }^{232} \mathrm{Th}$ from 50 locations on the territory of Subotica, North Serbia, were determined by gamma ray spectrometry. Based on the activity concentrations of investigated radionuclides, the absorbed gamma dose rate in the air was calculated. The mean values of activity concentrations were found to be $290 \mathrm{~Bq} / \mathrm{kg}$ for ${ }^{40} \mathrm{~K}, 20 \mathrm{~Bq} / \mathrm{kg}$ for ${ }^{226} \mathrm{Ra}$ and $18 \mathrm{~Bq} / \mathrm{kg}$ for ${ }^{232} \mathrm{Th}$. The total absorbed gamma dose rate varied between 24 and $46 \mathrm{nGy} / \mathrm{h}$. The mean value of $32 \mathrm{nGy} / \mathrm{h}$ was lower than the world average value.
\end{abstract}

Key words: Radium, thorium, potassium, exposure, dose

DOI: $10.21175 / \operatorname{RadProc} .2016 .17$

\section{INTRODUCTION}

Natural radionuclides in soil generate a significant component of the background radiation exposure of the population [1]. The natural radioactivity in soil mainly comes from the uranium and thorium decay series and potassium [2]. Obviously, the actual level of radiation caused by the radionuclide content of rocks and soil varies widely from place to place and the actual background contribution to the external gamma dose rate at a given location can be determined only by measurements. Thus, the dose rate depends on the geological location [3].

Numerous studies have been conducted to assess the radiation exposure due to these radionuclides and the results obtained are exploited to enrich the world's data bank, greatly needed for evaluating worldwide average values of radiometric and dosimetric quantity [4]. Investigation of soil radioactivity receives particular attention worldwide. These results serve as reference information to assess any changes in background level due to any artificial influences on the environment. Baseline data of this type are of importance in making estimations of population exposures. Concentrations in soil and their mutual relationships are presented.

The aim of this work is to determine the activity concentrations of ${ }^{226} \mathrm{Ra},{ }^{232} \mathrm{Th}$ and ${ }^{40} \mathrm{~K}$ in the soil samples collected from the territory of Subotica, the area with specific geological settings, using gamma ray spectrometry and to calculate the corresponding absorbed gamma dose rate in the air.

\subsection{Study area}

Subotica is the most northern city in the Republic of Serbia located on the latitude of $46^{\circ} 5^{\prime} 55^{\prime \prime}$ North and the longitude of $19^{\circ} 39^{\prime} 47^{\prime \prime}$ East. By the 2011 census, it has 105,681 inhabitants and it is the second largest city in the Autonomous Province of Vojvodina and the sixth in the Republic of Serbia. Subotica and its surroundings have a continental climate with average annual temperature of $11.4^{\circ} \mathrm{C}$. The city is located in the Panonian Plane on $1,008 \mathrm{~km}^{2}$ [5].

Subotica and its nearest surroundings are built out of loess and loess formations but their thickness is much smaller than in the most parts of Vojvodina, even though both are parts of the edge of the former Pannonian Sea. Sandy soil dominates in Subotica. This sand has two important characteristics: it is free of carbonate, on the surface it has a strong capability of water absorption (it is wet on a relatively low depth, even in summers). Its geomorphological characteristics are homogeneity and plains. Major features of this terrain are subsidence of sediments from Pleistocene and Holocene that are mostly spread through the creation of Paleozoic and Mesozoic formations. The whole Pannonian Basin was underwater which indicates a very intensive subsidence of marine and freshwater formations. By the step-by-step paving of the Sarmatian Sea and the recent part of Tethys, the ocean land was formed in this part of Europe where these weakly tied segments came to the surface where they were exposed to glacier, water or wind erosion during ice and semi-ice phases [6].

\footnotetext{
*1jmandic@vin.bg.ac.rs
} 


\section{MATERIALS AND METHODS}

The samples of undisturbed soils were collected from 50 locations in urban area of Subotica (about 60 $\mathrm{km}^{2}$ ) during 2013-2015. From each location, 3-4 subsamples were collected by the template method [7], up to the depth of $10 \mathrm{~cm}$, and then mixed (put together) into one composite sample Samples were dried at $105{ }^{\circ} \mathrm{C}$ to a constant weight and then homogenized. The homogenized samples were placed in $0.5 \mathrm{~L}$ Marinelli beakers. The beakers were hermetically sealed and kept aside for about a month to ensure the equilibrium between ${ }^{226} \mathrm{Ra}$ and its daughters before being taken for the gamma spectrometric analysis.

The measurements were performed using p-type high-purity germanium detector ORTEC-AMATEC, (relative efficiency $49 \%$ and resolution $1.95 \mathrm{keV}$, for ${ }^{60} \mathrm{Co}$ at $1.33 \mathrm{MeV}, 8192$ channels) shielded with $10 \mathrm{~cm}$ lead internally lined with $2 \mathrm{~mm}$ copper foil. The weight of each sample was approximately $0.5 \mathrm{~kg}$. The activity of each sample was measured for $60 \mathrm{ks}$. A mixed calibration source MBSS 2 (total activity $38 \mathrm{kBq}$ on 16 august $2010\left({ }^{241} \mathrm{Am},{ }^{109} \mathrm{Cd},{ }^{139} \mathrm{Ce},{ }^{57} \mathrm{Co},{ }^{60} \mathrm{Co},{ }^{137} \mathrm{Cs},{ }^{113} \mathrm{Sn}\right.$, ${ }^{85} \mathrm{Sr},{ }^{88} \mathrm{Y},{ }^{203} \mathrm{Hg}$ ) from the Czech Metrological Institute was used for efficiency calibration in the same geometry as the measured samples.

For the purpose of quality assurance, independent checks on calibration were performed using two standard reference materials from the International Atomic Energy Agency (IAEA-385) and the Environmental Measurement Laboratory, United States Department of Energy (QAP-9803). The counting errors were $5-10 \%$. The activity of ${ }^{226} \mathrm{Ra}$ was evaluated from the gamma ray of $609.3 \mathrm{keV}$ of ${ }^{214} \mathrm{Bi}$ and $351.9 \mathrm{keV}$ of $214 \mathrm{~Pb}$, while 911.2 and $969.1 \mathrm{keV}$ gamma-ray lines emitted by ${ }^{228} \mathrm{Ac}$ and $238.6 \mathrm{keV}$ emitted by ${ }^{212} \mathrm{~Pb}$ was used to determine ${ }^{232} \mathrm{Th}$. The activity of ${ }^{40} \mathrm{~K}$ was determined using its $1460.8 \mathrm{keV}$ gamma-ray line, taken into account all systematic and random uncertainties. The minimum detectable activity for each radionuclide was determined from the background radiation spectrum for the same counting time as for soil samples and was estimated to be 0.4 $\mathrm{Bq} / \mathrm{kg}$ for ${ }^{226} \mathrm{Ra}, 0.8 \mathrm{~Bq} / \mathrm{kg}$ for ${ }^{232} \mathrm{Th}$ and for $2.0 \mathrm{~Bq} / \mathrm{kg}$ ${ }^{40} \mathrm{~K}$.

Gamma Vision 32 was used to process the obtained spectra [8]. The statistical evaluation of the obtained results was performed using the statistical package SPSS 10.0 for Windows[9].

\subsection{Absorbed gamma dose rate}

The external gamma dose rate in the air at $1 \mathrm{~m}$ above ground level was calculated from the measured activity concentrations of ${ }^{226} \mathrm{Ra},{ }^{232} \mathrm{Th}$ and ${ }^{40} \mathrm{~K}$ in the

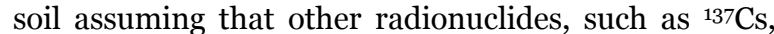
${ }^{90} \mathrm{Sr}$ and the ${ }^{235 \mathrm{U}}$ series, can be neglected as they contribute very little to the total dose from the environmental background. The calculations were performed according to the following equation (1):

$$
\mathrm{D}=0.462 \mathrm{~A}_{\mathrm{Ra}}+0.604 \mathrm{~A}_{\mathrm{Th}}+0.042 \mathrm{~A}_{\mathrm{K}}
$$

where $A_{R a}, A_{T h}$, and $A_{K}$ are activity concentrations (Bq $\mathrm{kg}^{-1}$ ) of ${ }^{226} \mathrm{Ra},{ }^{232} \mathrm{Th}$ and ${ }^{40} \mathrm{~K}$, respectively [10-12].

\section{RESULTS AND DISCUSSION}

Descriptive statistics for activity concentrations of primordial radionuclides in soil samples collected in the Subotica area is presented in Table 1.

Table 1. Descriptive statistics of activity concentrations of ${ }^{226} \mathrm{Ra},{ }^{232} \mathrm{Th}$ and ${ }^{40} \mathrm{~K}$ for all analyzed soil samples

\begin{tabular}{|l|c|c|c|}
\hline \multirow{2}{*}{ Parameter } & \multicolumn{3}{|c|}{ Activity concentration $\left(\mathrm{Bq} \mathrm{kg}{ }^{-1}\right)$} \\
\cline { 2 - 4 } & ${ }^{226} \mathrm{Ra}$ & ${ }^{232} \mathrm{Th}$ & $40 \mathrm{~K}$ \\
\hline Mode & 19 & 15 & 350 \\
\hline Mean & 20 & 18 & 290 \\
\hline Median & 19 & 18 & 290 \\
\hline St. deviation & 5 & 3 & 63 \\
\hline Minimum & 12 & 13 & 260 \\
\hline Maximum & 33 & 23 & 390 \\
\hline
\end{tabular}

The mean activity concentrations for ${ }^{226} \mathrm{Ra}{ }^{232} \mathrm{Th}$ and ${ }^{\circ} \mathrm{K}$ were lower than the averages for Serbia, i.e. 33 $\mathrm{Bq} / \mathrm{kg}, 36 \mathrm{~Bq} / \mathrm{kg} 510 \mathrm{~Bq} / \mathrm{kg}$ for these radionuclides, respectively [10], which is the consequence of the difference in geological structures of the study area and the whole territory of Serbia. The territory of Serbia includes a great variety of rock complexes (magmatic, sedimentary, metamorphic) which are markedly different in age, genesis, mineral content, petrochemical and geochemical characteristics and thus in the content of radionuclides. The activity concentrations of analyzed radionuclides are similar to those obtained nearby Palic $\left(310 \mathrm{~Bq} / \mathrm{kg}\right.$ for ${ }^{40} \mathrm{~K}, 19.9$ $\mathrm{Bq} / \mathrm{kg}$ for ${ }^{226} \mathrm{Ra}$ and $23.5 \mathrm{~Bq} / \mathrm{kg}$ for ${ }^{232} \mathrm{Th}$ ) [13] Activity concentrations of analyzed radionuclides in soil are lower than those reported for the neighboring Hungary $\left\{{ }^{40} \mathrm{~K}(97-701) \mathrm{Bq} / \mathrm{kg},{ }^{226} \mathrm{Ra}(17-93) \mathrm{Bq} / \mathrm{kg}\right.$ and ${ }^{232} \mathrm{Th}$ $(15-55) \mathrm{Bq} / \mathrm{kg}\}$ [2].They are of the same order of magnitude as activity concentrations in the soil of Csongrad, the city in Southeast Hungary (about $130 \mathrm{~km}$ far from Subotica) with similar geological substrate $\left\{{ }^{40} \mathrm{~K}(276-453) \mathrm{Bq} / \mathrm{kg},{ }^{226} \mathrm{Ra}(14-44) \mathrm{Bq} / \mathrm{kg},{ }^{232} \mathrm{Th}\left(14^{-}\right.\right.$ 35) $\mathrm{Bq} / \mathrm{kg}\}$ [14].

The values of total gamma dose rates varied between 24 and $46 \mathrm{nGy} \mathrm{h}^{-1}$ with the mean value of 32 $\mathrm{nGy} \mathrm{h}^{-1}$. According to UNSCEAR (2000) [2], the dose rate in air outdoors from terrestrial gamma rays in normal circumstances is approximately $58 \mathrm{nGy} \mathrm{h}^{-1}$ with average ranges by country from 1 to $1100 \mathrm{nGy} \mathrm{h}^{-1}$. The mean value for soils analyzed in this study is about $40 \%$ lower than the world average. The contribution to the total absorbed gamma dose rate by ${ }^{226} \mathrm{Ra},{ }^{232} \mathrm{Th}$ and ${ }^{4} \mathrm{~K}$ was $29 \%, 34 \%$ and $37 \%$, respectively. The contribution of each radionuclide to the total dose depends primarily on the soil type and geological background of each investigated location. The range and the mean values of the absorbed gamma dose rate due to ${ }^{226} \mathrm{Ra},{ }^{232} \mathrm{Th}$ and ${ }^{40} \mathrm{~K}$ obtained for Subotica are compared with values reported for cities worldwide (Table 2). 
Table 2. Absorbed gamma dose rates in cities from different parts of the world compared with those obtained in the present study

\begin{tabular}{|l|c|}
\hline City & $\mathrm{D}\left(\mathrm{nGy} \mathrm{h}^{-1}\right)$ \\
\hline Bangalore, India [15] & $117(61-202)$ \\
Csongrad, Hungary [14] & 38 \\
Debrecen, Hungary [14] & 24 \\
Faisalabad, Pakistan[16] & $73(62-79)$ \\
Istanbul, Turkey[17] & $49(15-71)$ \\
Palic, Serbia[13] & 36 \\
Horgos, Serbia[13] & 32 \\
Belgrade, Serbia[18] & $60(25-90)$ \\
Alkharje, Saudi Arabia [19] & $24(15-30)$ \\
Tafila, Jordan [20] & $40(22-63)$ \\
Tripoli, Libya [21] & $23(20-24)$ \\
Windhoek, Namibia [22] & $56(41-70)$ \\
Zacatecas, Mexico [23] & $45(28-67)$ \\
Zahedan, Iran [24] & $158(16-300)$ \\
Subotica,this study & $32(24-46)$ \\
\hline
\end{tabular}

It can be seen that the mean value of the gamma dose rate observed in the present study ( $\left.32 \mathrm{nGy} \mathrm{h}^{-1}\right)$ lies within the values reported worldwide. It is comparable with those reported for the cities of Palic and Horgos [13], which are close to Subotica. The obtained results were similar to cities that have a dominant sandy soil composition, such as Alkharje, Saudi Arabia [19] and Tripoli, Libya [21]. These differences in the terrestrial radioactivity and the associated external exposure due to gamma radiation, are caused by geological and geographical specificities of investigated areas.

\section{CONCLUSIONS}

The mean values of activity concentrations of analyzed radionuclides were found to be $290 \mathrm{~Bq} / \mathrm{kg}$ for ${ }^{40} \mathrm{~K}, 20 \mathrm{~Bq} / \mathrm{kg}$ for ${ }^{226} \mathrm{Ra}$ and $18 \mathrm{~Bq} / \mathrm{kg}$ for ${ }^{232} \mathrm{Th}$. The mean calculated value of the total absorbed gamma dose rate of $32 \mathrm{nGy} / \mathrm{h}(24-46 \mathrm{nGy} / \mathrm{h})$ was lower than the world average. The obtained activity concentrations and total gamma dose rates are lower than the world average values. The results obtained in this study may be used for the preliminary estimation of the population exposure due to natural radionuclides. Further investigation is needed before definite conclusions on this issue are drawn.

Acknowledgement: This work was supported by the Ministry of Education and Science of the Republic of Serbia (Project No. III 43009).

\section{REFERENCES}

1. B. Merdanoglu and N. Altinsoy, "Radioactivity Concentrations and Dose Assessment for Soil Samples from Kestanbol Granite Area, Turkey," Rad. Prot. Dosim., vol. 121, pp. 399-405, Dec. 2006

2. Exposures from Natural Radiation Sources, in "Sources and Effects of Ionizing Radiation," UNSCEAR, vol. 1, annex B, pp. 83-156, 2000.

3. A. Martin, S.A. Harbinson, An Introduction to Radiation Protection, New York (NY), USA: John Wiley \& Sons Inc, 1972

4. S. Dragović, Lj. Janković Mandić, R. Dragović, M Đorđević, M. Đokić, J. Kovaćević, "Lithogenic
Radionuclides in Surface Soils of Serbia: Spatial Distribution and Relation to Geological Formations," J.Geochem. Explor., vol. 142, pp. 4-10, July 2014

5. „Попис становништва, домаћинстава и станова 2011. у Републици Србији,“ Републички завод за статистику, Београд, 2012. (“2011 Census of Population, Households and Dwellings in the Republic of Serbia," Statistical Office of the Republic of Serbia, Belgrade, 2012)

6. "Glavni rudarski projekat, eksploatacija ciglarske gline u Subotici," Beograd, 1985. ("Main mining project, exploitation of brick clay in the brick drive bay 1 in Subotica," Belgrade, 1985)

7. Soil Sampling for Environmental Contaminants, IAEATECDOC-1415, IAEA, Vienna, Austria, 2004

8. Ortec, Oak Ridge, (TN), USA, 2001, Gamma Vision 32, Gamma-Ray Spectrum Analysis and MCA Emulation, Ver. 5.3

9. SPSS Inc., Chikago (IL), USA, 1999, Statistical Package for the Social Sciences (SPSS) Ver. 10.0

Retrieved from: http://www.spss.com

10. S. Dragović, Lj. Janković Mandić, R. Dragović, M. Đorđević, "Natural and Man-Made Radionuclides in Soils as Sources of Radiation Exposure," in Radiation Exposure: Sources, Impacts and Reduction Strategies, D. Balenović and E. Stimac (Eds.), New York (NY), USA: Nova Science, 2012, pp. 1-42

11. P. Jacob, H.G. Paretzke, H. Rosenbaum, and M. Zankl, "Effective Dose Equivalents for Photon Exposure from Plane Sources on the Ground," Rad. Prot. Dosim., vol.14, no. 4, pp. 290-310, 1986

12. K.C. Leung, S.Y. Lau and C.B. Poon, "Gamma Radiation Dose from Radionuclides in Hong Kong Soil," $J$. Environ. Radioact., vol. 11, no. 3, pp. 279-290, 1990

13. I. Bikit et al., "Radioactivity of the Soil in Vojvodina (Northern Province of Serbia and Montenegro," $J$. Environ. Radioact., vol. 78, no. 1, pp. 11-19, Sep. 2004

14. Z. Papp, "Natural Radioactivity in the Soils of Some Eastern Counties of Hungary," Rad. Prot. Dos., vol. 141, no. 1 , pp. 56-63, 2010

15. N.G. Shiva Prasad, N. Nagaiah, G.V. Ashok, and N. Karunakara, "Concentrations of ${ }^{226} \mathrm{Ra},{ }^{232} \mathrm{Th}$, and ${ }^{40} \mathrm{~K}$ in the Soils of Bangalore Region, India," Health Phys., vol. 94, no. 3, pp. 264-271, Mar. 2008

16. M. Tufail, N. Akhtar, and M. Waqas, "Measurement of terrestrial radiation for assessment of gamma dose from cultivated and barren saline soils of Faisalabad in Pakistan," Radiat. Meas., vol. 41, no. 4, pp. 443-451, Apr. 2006

17. G. Karahan, A. Bayulken, "Assessment of Gamma Dose Rates Around Istanbul (Turkey)," J. Environ. Radioact., vol. 47, no. 2, pp. 213-221, Jan. 2000

18. Lj. Jankovic Mandic, and S. Dragovic, "Assessment of terrestrial gamma exposure to the population of Belgrade (Serbia)," Rad. Prot. Dosim., vol. 140, no. 4, pp. 369-377, 2010

19. H. Orabi, A. Al-Shareaif and M. El Galefi, "Gamma-Ray Measurements of Naturally Occuring Radioactive Sample from Alkharje City," J. Radioanal. Nucl. Chem., vol. 269, no. 1, pp. 99-102, July 2006

20. O. Abu-Haija, Determination of Natural Radionuclides Concentrations in Surface Soil in Tafila/Jordan, Mod. Appl. Sci., vol. 6, no. 3, pp. 87-90, 2012

21. M.A. Shenber, "Measurement of Natural Radioactivity Levels in Soil in Tripoli," Appl. Radiat. Isot., vol. 48, no. 1, pp. 147-148, Jan. 1997

22. J.A. Oyedele, "Assessment of the Natural Radioactivity in the Soils of Windhoek City Namibia, Southern Africa," Rad. Prot. Dosim., vol. 121, no. 3, pp. 337-340, Dec. 2006

23. F. Mireles, J.I. Davila, L.L. Quirino, J.F. Lugo, J.L. Pinedo and C. Rios, "Natural Soil Gamma Radioactivity Levels and Resultant Population Dose in the Cities of Zacatecas and Guadalupe, Zacatecas, Mexico," Health Phys., vol. 84, no. 3, pp. 368-372, Mar. 2003 
24. S.A. Hosseini, "Naturally Occuring Radioactivity in the City and across Nearby Cities in Iran," J. Appl. Sci., vol. 7, no. 20, pp. 3091-3095, 2007 